University of Nebraska - Lincoln

DigitalCommons@University of Nebraska - Lincoln

USDA National Wildlife Research Center - Staff Publications
U.S. Department of Agriculture: Animal and Plant Health Inspection Service

2012

\title{
Surveillance for Avian Influenza Viruses in Wild Birds in Denmark and Greenland, 2007-10
}

Charlotte Kristiane Hjulsager

Technical University of Denmark, ckhj@vet.dtu.dk

Solvej Østergaard Breum

Technical University of Denmark, sbre@vet.dtu.dk

Ramona Trebbien

Technical University of Denmark, ratre@vet.dtu.dk

Kurt Jensen Handberg

Aarhus University Hospital, kuhand@rm.dk

Ole Roland Therkildsen

Aarhus University, oth@dmu.dk

See next page for additional authors

Follow this and additional works at: https://digitalcommons.unl.edu/icwdm_usdanwrc

Part of the Life Sciences Commons

Hjulsager, Charlotte Kristiane; Østergaard Breum, Solvej; Trebbien, Ramona; Handberg, Kurt Jensen; Therkildsen, Ole Roland; Madsen, Jesper Johannes; Thorup, Kasper; Baroch, John A.; DeLiberto, Thomas J.; Larsen, Lars Erik; and Jørgensen, Poul Henrik, "Surveillance for Avian Influenza Viruses in Wild Birds in Denmark and Greenland, 2007-10" (2012). USDA National Wildlife Research Center - Staff Publications. 1146.

https://digitalcommons.unl.edu/icwdm_usdanwrc/1146

This Article is brought to you for free and open access by the U.S. Department of Agriculture: Animal and Plant Health Inspection Service at DigitalCommons@University of Nebraska - Lincoln. It has been accepted for inclusion in USDA National Wildlife Research Center - Staff Publications by an authorized administrator of DigitalCommons@University of Nebraska - Lincoln. 


\section{Authors}

Charlotte Kristiane Hjulsager, Solvej Østergaard Breum, Ramona Trebbien, Kurt Jensen Handberg, Ole

Roland Therkildsen, Jesper Johannes Madsen, Kasper Thorup, John A. Baroch, Thomas J. DeLiberto, Lars

Erik Larsen, and Poul Henrik Jørgensen 


\title{
Research Note-
}

\section{Surveillance for Avian Influenza Viruses in Wild Birds in Denmark and Greenland, 2007-10}

\author{
Charlotte Kristiane Hjulsager, ${ }^{\mathrm{AF}}$ Solvej Østergaard Breum, ${ }^{\mathrm{A}}$ Ramona Trebbien, ${ }^{\mathrm{A}}$ Kurt Jensen Handberg, ${ }^{\mathrm{B}}$ \\ Ole Roland Therkildsen, ${ }^{\mathrm{C}}$ Jesper Johannes Madsen, ${ }^{\mathrm{D}}$ Kasper Thorup, ${ }^{\mathrm{D}}$ John A. Baroch, ${ }^{\mathrm{E}}$ Thomas J. DeLiberto, ${ }^{\mathrm{E}}$ \\ Lars Erik Larsen, ${ }^{\mathrm{A}}$ and Poul Henrik Jørgensen ${ }^{\mathrm{A}}$ \\ ${ }^{A}$ Technical University of Denmark, National Veterinary Institute, Bülowsvej 27, 1790 Copenhagen V, Denmark \\ ${ }^{B}$ Aarhus University Hospital, Clinical Microbiology Department, Brendstrupsgaardsvej 100, 8200 Aarhus N, Denmark \\ $\mathrm{C}^{\mathrm{C}}$ Aarhus University, Department of Bioscience, Grenåvej 14, 8410 Rønde, Denmark \\ ${ }^{\mathrm{D}}$ University of Copenhagen, Natural History Museum of Denmark, Universitetsparken 15, 2100 Copenhagen $\varnothing$, Denmark \\ ${ }^{\mathrm{E}}$ U.S. Department of Agriculture, Animal and Plant Health Inspection Service, Wildlife Services, National Wildlife Disease Program, \\ Fort Collins, CO 80521
}

Received 10 April 2012; Accepted 5 July 2012; Published ahead of print 10 July 2012

SUMMARY. In Denmark and Greenland, extensive surveillance of avian influenza (AI) viruses in wild bird populations has been conducted from 2007 through 2010. In Denmark, the surveillance consisted of passive surveillance of wild birds found dead or sick across Denmark and active surveillance of apparently healthy live birds in waterfowl reservoirs and along migratory flyways, birds living in proximity to domestic poultry, and hunted game birds. Dead birds were sampled by oropharyngeal swabbing. Healthy live wild birds were captured with nets, traps, or by hand and were sampled by swabbing of the oropharyngeal and cloacal tracts, or swabs were collected from fresh fecal droppings. Hunted game birds were delivered to game-handling establishments, where each bird was sampled by oropharyngeal and cloacal swabbing. During the 2007-10 period, a total of 11,055 wild birds were sampled in Denmark, of which 396 were birds that were found dead. In Greenland, samples were collected mainly from fecal droppings in breeding areas. Samples from 3555 live and apparently healthy wild birds were tested. All swab samples were tested by pan-influenza reverse transcriptase-PCR (RT-PCR), and the positive samples were further tested by H5/H7 specific RT-PCRs. H5/H7-positive samples were subjected to hemagglutination cleavage site sequencing for pathotyping. In addition, all RT-PCRpositive samples were subjected to virus isolation, and the virus isolates were subsequently subtyped. In Denmark, low pathogenic (LP) $\mathrm{H} 5$ viruses were detected throughout the period, in addition to a few LPAI H7 and several other subtypes. In Greenland, very few samples were positive for AI. None of them were found to be of the H5 or H7 subtypes by RT-PCR. Isolation of these viruses in eggs was unsuccessful; thus, they were not subtyped further. The findings did, however, demonstrate the presence of LPAI viruses in Greenland. For several water bird species overwintering in North America and northwest Europe, respectively, Greenland constitutes a common breeding area. This raises the possibility that viruses could be transmitted to North America via Greenland and vice versa. In Denmark, the screenings for AI showed LPAI viruses to be naturally occurring in the wild bird population, particularly in waterfowl. The occurrence of AI viruses in the wild bird population may pose a risk for AI infections in Danish poultry.

RESUMEN. Nota de Investigación —Vigilancia de los virus de influenza aviar en aves silvestres en Dinamarca y en Groenlandia, 2007-2010.

Se ha llevado a cabo en Dinamarca y en Groenlandia una vigilancia extensiva contra el virus de la influenza aviar en poblaciones de aves silvestres desde el año 2007 hasta el año 2010. En Dinamarca, la vigilancia ha consistido en la vigilancia pasiva de las aves silvestres halladas muertas o enfermas en toda Dinamarca y la vigilancia activa de aves vivas aparentemente sanas, en los reservorios de aves acuáticas y a lo largo de las rutas migratorias. También de las aves que viven en proximidad con aves comerciales y de las aves deportivas que han sido presas de caza. Se recolectaron muestras de hisopos orofaríngeos de aves muertas. Se capturaron aves silvestres vivas con redes, trampas, o manualmente y se recolectaron muestras de hisopos orofaríngeos y cloacales, o de hisopos recolectados de excreciones fecales frescas. Se entregaron aves de caza ya capturadas a establecimientos donde se mantenían y manejaban este tipo de aves, donde se recolectaron muestras de hisopos orofaríngeos y cloacales de cada ave. Durante el período entre los años $2007 \mathrm{al}$ 2010, se recolectaron un total de 11,055 muestras de aves silvestres en Dinamarca, de las cuales, 396 eran de aves que fueron encontradas muertas. En Groenlandia, las muestras fueron recolectadas principalmente de excreciones fecales en las zonas de reproducción. Se analizaron muestras de 3,555 aves silvestres vivas y aparentemente sanas. Todas las muestras de hisopos fueron analizadas por un método de transcripción reversa y PCR (RT-PCR) que detecta todos los subtipos de influenza, y las muestras positivas fueron analizadas por un método específico de RT-PCR para los subtipos H5/H7. Las muestras positivas por el método de RT-PCR para H5/H7 fueron analizadas mediante la secuenciación del sitio de disociación de la hemaglutinina para la tipificación patogénica. Además, todas las muestras positivas por RT-PCR fueron sometidas a aislamiento del virus, y los aislamientos virales fueron subtipificados posteriormente. En Dinamarca, se detectaron virus H5 de baja patogenicidad durante todo el período, además de unos cuantos virus de baja patogenicidad subtipo $\mathrm{H} 7$ aviar y otros subtipos diferentes. En Groenlandia, muy pocas muestras resultaron positivas para la influenza aviar. Ninguno de los virus resultó ser de los subtipos $\mathrm{H} 5$ o $\mathrm{H} 7$ mediante RT-PCR. El aislamiento de estos virus en huevos no tuvo éxito, por lo que no se realizó subtipificación posterior. Los resultados, sin embargo, demuestran la presencia de virus de baja patogenicidad en Groenlandia. Para varias especies de aves acuáticas que hibernan en América del Norte y en el noroeste de Europa, respectivamente, Groenlandia constituye un área reproductiva común.

${ }^{\mathrm{F}}$ Corresponding author: E-mail: ckhj@vet.dtu.dk 
Esto plantea la posibilidad de que el virus podría ser transmitido a América del Norte a través de Groenlandia, o viceversa. En Dinamarca, las pruebas de detección del virus de influenza aviar de baja patogenicidad mostraron la presencia de virus de la influenza de baja patogenicidad de forma natural en la población de aves silvestres, especialmente en aves acuáticas. La aparición de virus de la influenza aviar en la población de aves silvestres pueden representar un riesgo de infecciones con el virus de la influenza aviar en la avicultura danesa.

Key words: avian influenza virus, wild birds, surveillance, Denmark, Greenland

Abbreviations: $\mathrm{AI}=$ avian influenza; $\mathrm{HA}=$ hemagglutination; $\mathrm{HP}=$ highly pathogenic; $\mathrm{LP}=$ low pathogenic; $\mathrm{M}$ gene $=\mathrm{Matrix}$ gene; RT-PCR = reverse transcriptase-polymerase chain reaction

Waterfowl and shorebirds are considered the natural reservoirs of avian influenza (AI) viruses, and migratory movements by these birds are believed to play a role in the spread of AI (12).

Greenland has long been recognized as a "stepping stone" for occasional migratory bird movements between North America and Europe (7) and has been suggested as a plausible "springboard" for transAtlantic spread of AI (13). Interregional transmission of AI has been demonstrated by the discovery of European lineage hemagglutinin genes (subtype H2) in eastern North American shorebirds at Delaware Bay (11).

Since the spread of H5N1 highly pathogenic (HP) AI from Asia to Europe and Africa, surveillance for AI in poultry and wild birds has been extensively conducted in Europe $(2,6)$. Low pathogenic (LP) viruses of $\mathrm{H} 5$ and $\mathrm{H} 7$ subtype in addition to other subtypes are reported regularly from wild birds and sporadically from poultry. Outbreaks of AI in Danish poultry are rare; however, LP H5N2 was diagnosed in quarantined ostriches in 1996 (10), LP H5N7 was diagnosed in mallards bred for restocking of game in $2003(3,5)$, and LP H7N1 was diagnosed in a flock of domestic geese in 2008 (15) and in two flocks of mallards in 2010 (authors' unpubl. data). HPAI has only been discovered in Denmark in 2006, when HP H5N1 infections were discovered in 44 wild birds and in a single backyard poultry flock (4).
In Denmark and Greenland, the surveillance is aimed at detecting viruses of both HPAI subtypes $\mathrm{H} 5$ and $\mathrm{H} 7$ as well as LPAI viruses. The Danish surveillance program consisted of passive surveillance of diseased and dead wild birds found in nature and active surveillance of live, healthy birds in waterfowl reservoirs and along migratory flyways (Fig. 1), birds living in proximity to domestic poultry, and hunted game birds. In Greenland, active surveillance was conducted by sampling in breeding areas. Here we report our findings from the annual AI surveillance of the wild bird populations in Denmark and Greenland during the 2007-10 period.

\section{MATERIALS AND METHODS}

Bird sampling. In Denmark, samples were collected mainly from Anseriformes (ducks, geese, and swans) and Charadriiformes (gulls, terns, and shorebirds) wild birds and from dead birds of prey (Table 1). In 2007, the target species were defined as species that could occur near poultry farms. The focus was on Passeriformes species, which have a high probability of contact with poultry, but also raptors, owls, pigeons, and waterfowl. From 2008 onward, the European Commission guidelines were followed (Decision 2007/268/EC of 13/IV/2007, object C), focusing on larger bird species, especially water birds such as swans,

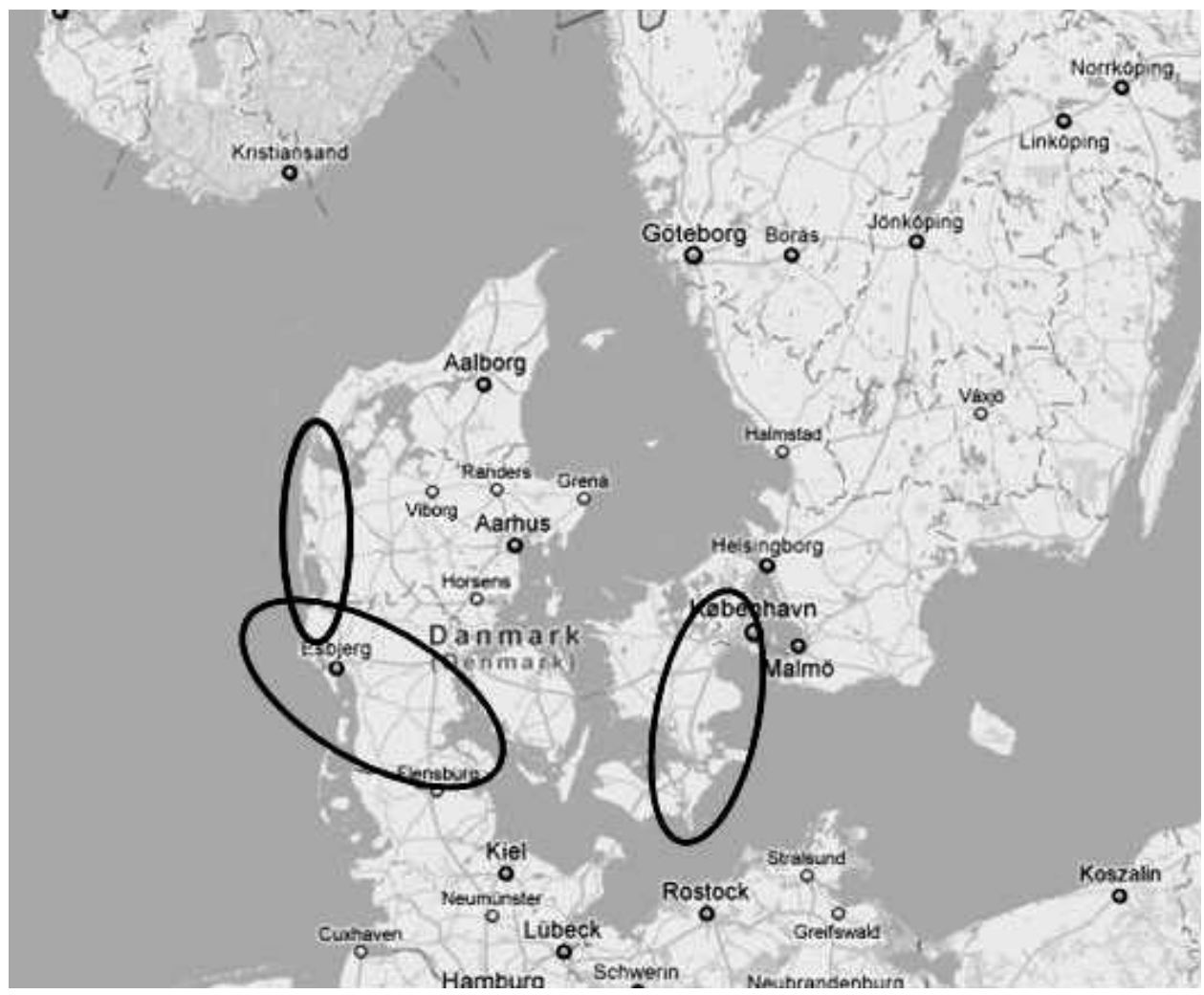

Fig. 1. Main sampling locations for AIV active surveillance in wild birds in Denmark. 
Table 1. Overview of the bird species sampled in Denmark in this study and the distribution of positive samples.

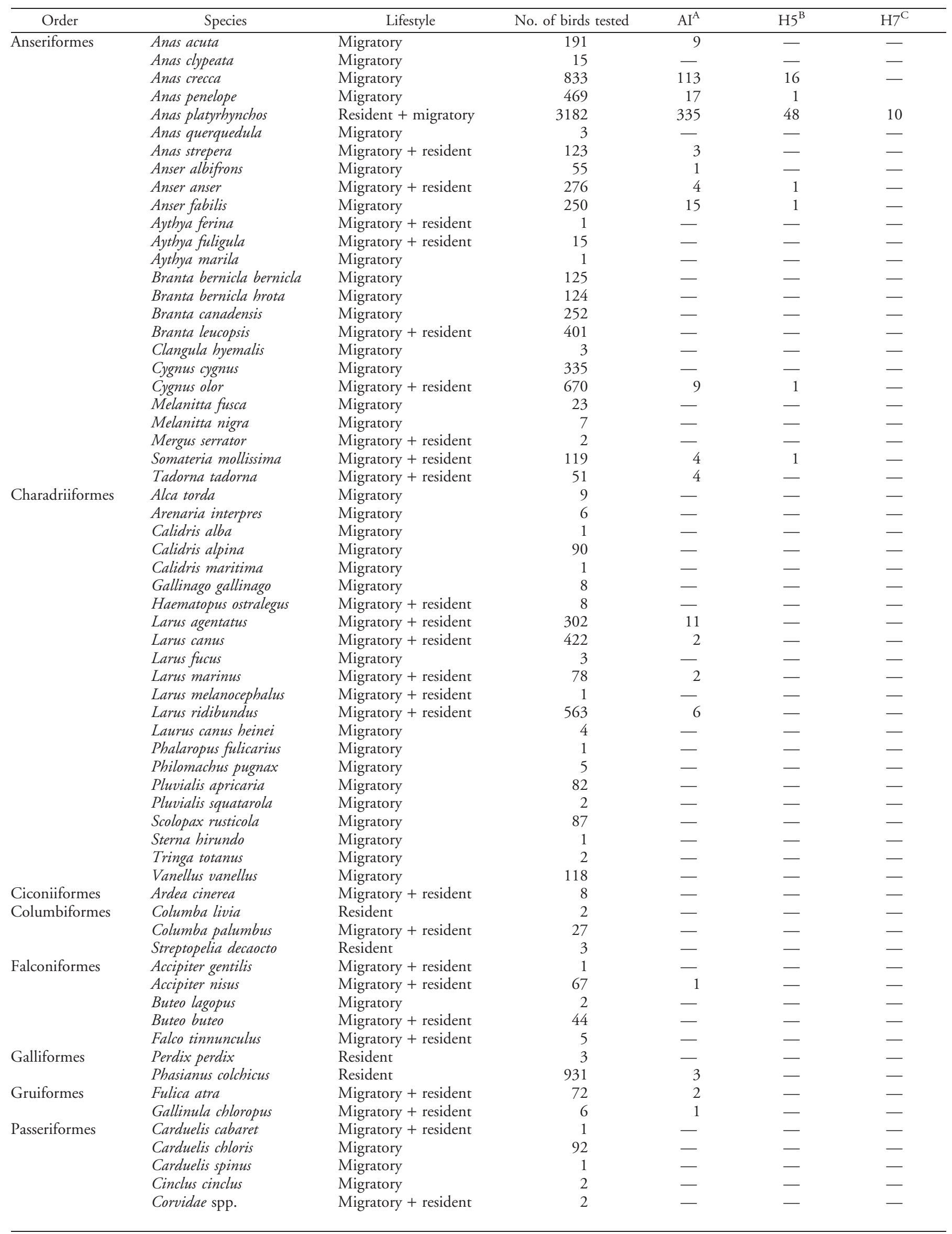


Table 1. Continued.

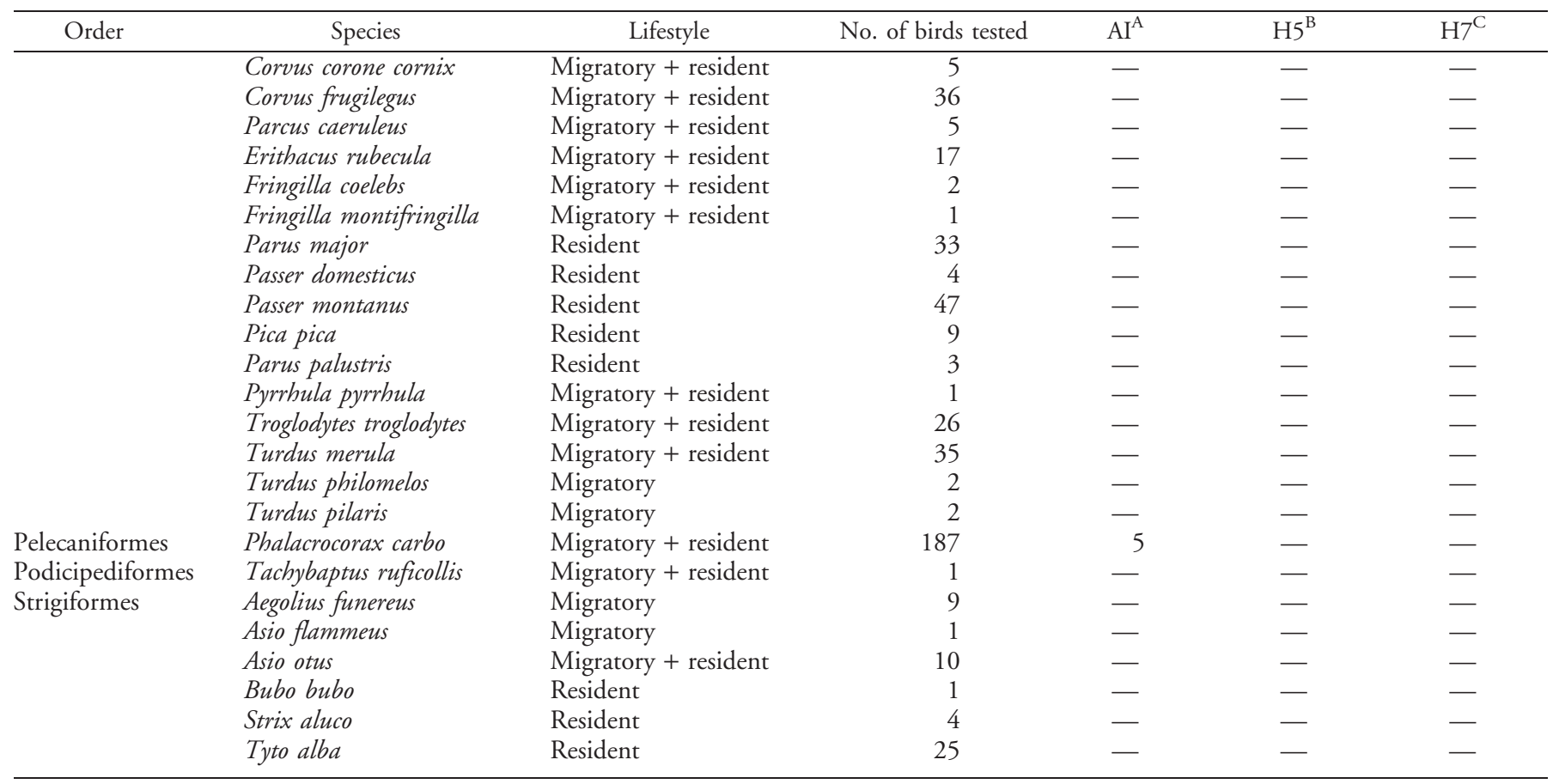

${ }^{\mathrm{A}}$ Number of samples positive by RT-PCR for influenza A virus.

${ }^{\mathrm{B}} \mathrm{Number}$ of samples subtyped as $\mathrm{H} 5$.

${ }^{\mathrm{C}}$ Number of samples subtyped as $\mathrm{H} 7$.

geese, ducks, coots, waders, and gulls. Secondary samples were also collected from birds of prey, barn owl, pigeons, crows, and starlings. In connection with objective $\mathrm{C}$, samples were collected from apparently healthy, live birds that were handled in connection with ongoing ringing activities in Denmark coordinated by the Natural History Museum of Denmark. Samples were mainly collected on Zealand, Falster, Lolland, Funen, and Southern Jutland.

For the Danish surveillance activities, three categories of birds were sampled: 1) "dead birds" were birds that were found dead in nature; 2) "live birds" were apparently healthy birds captured in traps, by nets, or by hand and released after sampling; or 3) shot game birds. Birds in the category "shot game" were hunted game birds, mainly pheasants and mallards, handed in to game-handling establishments for food production. "Dead birds" were sampled by oropharyngeal swabbing of carcasses in the laboratory, whereas "live birds" and "shot game" were sampled by oropharyngeal and cloacal swabbing in the field or at the game-handling establishment, respectively. In some cases "live birds" were instead sampled from their fresh droppings.

In Greenland in 2007-08 a variety of species were sampled. Birds of the orders Anseriformes and Charadriiformes comprised most of the sampling targets, although some Falconiformes and Passeriformes species were also sampled. After results of the first $2 \mathrm{yr}$ of surveillance yielded no evidence of $\mathrm{AI}$ in the falcons and songbirds, the list of focal species was revised. In 2010, sampling focused upon resident mallards (Anas platyrynchus) and migratory gulls (Larus spp.) and geese (Anser spp., Branta spp.).

All samples from Greenland were included in the category of live birds. Swab samples were transported cooled to the laboratory in phosphatebuffered saline with antibiotics and fetal calf serum or brain heart infusion media (7). The samples were delivered to the laboratory either by the collectors or by mail. Samples were analyzed at the National Veterinary Institute in Denmark, with the exception of 307 samples from Canada geese and greater snow geese collected in northwest Greenland that were analyzed at the Cornell Animal Health Diagnostic Center in Ithaca, NY. The samples tested in the United States were combined cloacaloropharyngeal swabs. They were stored and transported in a nitrogen vapor shipper $(-150 \mathrm{C})$ and tested at the Cornell laboratory 8 days after being collected. Samples tested in Denmark were stored at $4 \mathrm{C}$ if the analyses were initiated within 7 days of arrival; otherwise the samples were frozen at $-80 \mathrm{C}$ until analysis. However, many samples from the 2010 collections were subjected to freezing at $-20 \mathrm{C}$ prior to analysis. In general, the logistics of transporting samples, especially from Greenland, to the laboratory may have resulted in suboptimal storage conditions for some samples prior to analysis.

Table 2. Summary of surveillance for avian influenza viruses in wild birds in Denmark, 2007-10.

\begin{tabular}{|c|c|c|c|c|}
\hline & 2007 & 2008 & 2009 & 2010 \\
\hline No. of dead birds (oropharyngeal swabs) & 196 & 71 & 77 & 52 \\
\hline No. of shot game (cloacal + oropharyngeal swabs) & 935 & 281 & 794 & 702 \\
\hline No. of live birds (cloacal + oropharyngeal swabs or fecal swabs) & 3993 & 885 & 1487 & $1587^{\mathrm{A}}$ \\
\hline AI RT-PCR-positive birds & 83 & 66 & $152^{\mathrm{B}}$ & $235^{\mathrm{B}}$ \\
\hline H5-positive birds ${ }^{\mathrm{C}}$ & 8 & 6 & 13 & 42 \\
\hline H7-positive birds ${ }^{\mathrm{C}}$ & 1 & 3 & 5 & 1 \\
\hline
\end{tabular}

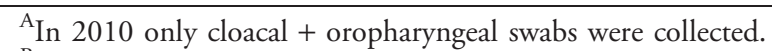

${ }^{\mathrm{B}}$ Of the birds positive for avian influenza, dead birds accounted for one bird in 2009 and three birds in 2010.

${ }^{\mathrm{C}}$ All $\mathrm{H} 5$ and $\mathrm{H} 7$ avian influenza viruses were LPAI. 
Table 3. Subtypes of avian influenza viruses isolated from wild bird samples in Denmark during 2007-10. For each year the number of viruses of each subtype is indicated with information on species and sample material from which these viruses were isolated. ${ }^{\mathrm{A}}$

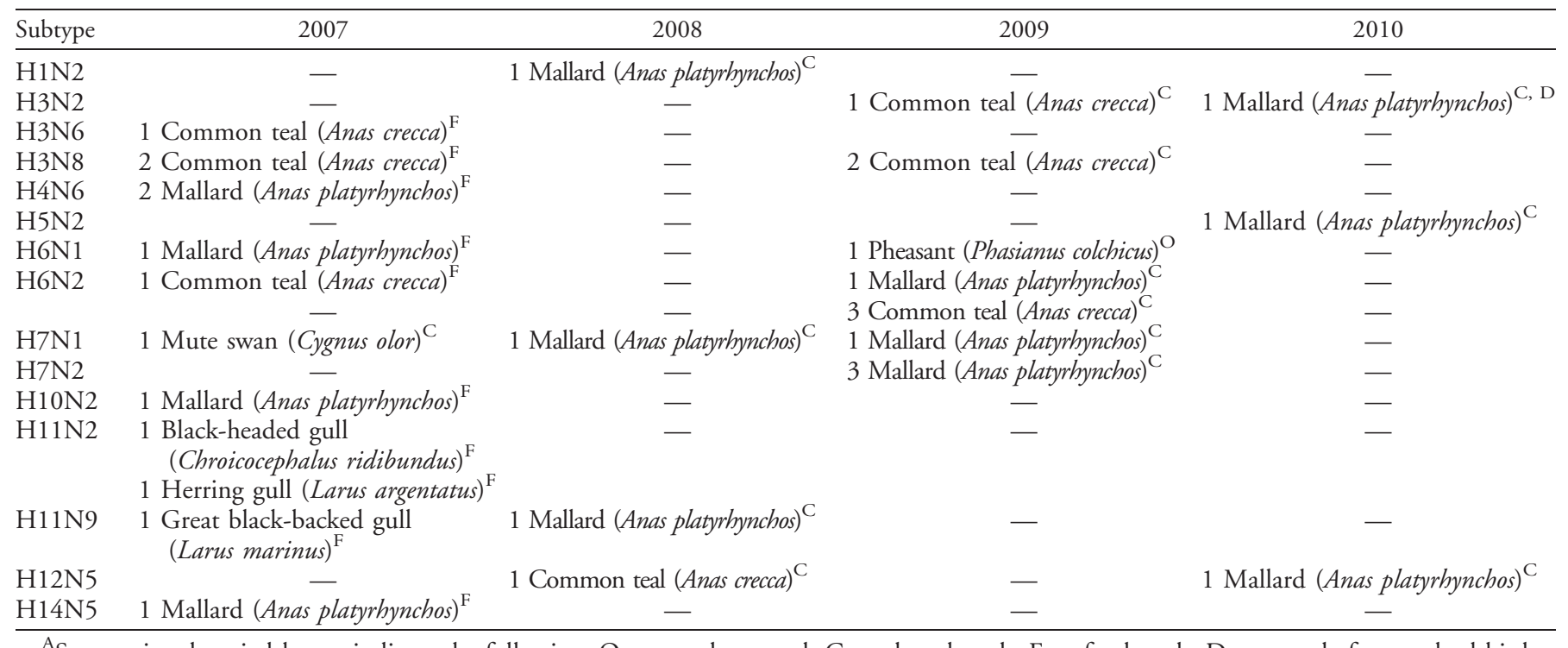

${ }^{\text {A }}$ Superscripted capital letters indicate the following: $\mathrm{O}=$ oropharyngeal; $\mathrm{C}=$ cloacal swab; $\mathrm{F}=$ fecal swab; $\mathrm{D}=$ sample from a dead bird.

Reverse transcriptase-PCR (RT-PCR) and virus isolation. Samples were tested by RT-PCR and by virus isolation. Total RNA was extracted with the RNeasy Mini Kit (QIAGEN, Copenhagen, Denmark), MagNa Pure LC Total NA Kit (Roche, Hvidovre, Denmark), or QIAsymphony RNA Kit (QIAGEN), according to instructions from the manufacturers. RT-PCR assays employed were as recommended by the World Organisation for Animal Health (OIE) reference laboratory in Weybridge $(7,14)$. All samples were screened with influenza A Matrix (M)gene RT-PCR to detect the presence of AI virus in the samples. Positive samples were subsequently tested in $\mathrm{H} 5$ and $\mathrm{H} 7$ subtype specific RT-
PCRs. The pathogenicity of $\mathrm{H} 5$ - and $\mathrm{H} 7$-positive samples was determined by sequencing across the hemagglutination (HA) cleavage site with KHA-1 and KHA-3 primers for H5 and GK7.3 and GK7.4 primers for $\mathrm{H} 7$ viruses (14). PCR-positive samples were inoculated into the allantoic cavity of 8-to-10-day-old embryonated specific-pathogenfree chicken eggs (Lohrmann Tierzucht, Cuxhaven, Germany) for virus isolation (7). Briefly, swab eluates including antibiotics were inoculated into the allantoic cavity and incubated in a humidified atmosphere at $37 \mathrm{C}$ and candled daily. Allantoic fluid harvested from eggs with dead embryos and from eggs incubated for 6 days was examined for

Table 4. Overview of the surveillance for avian influenza viruses in wild birds in Greenland in this study.

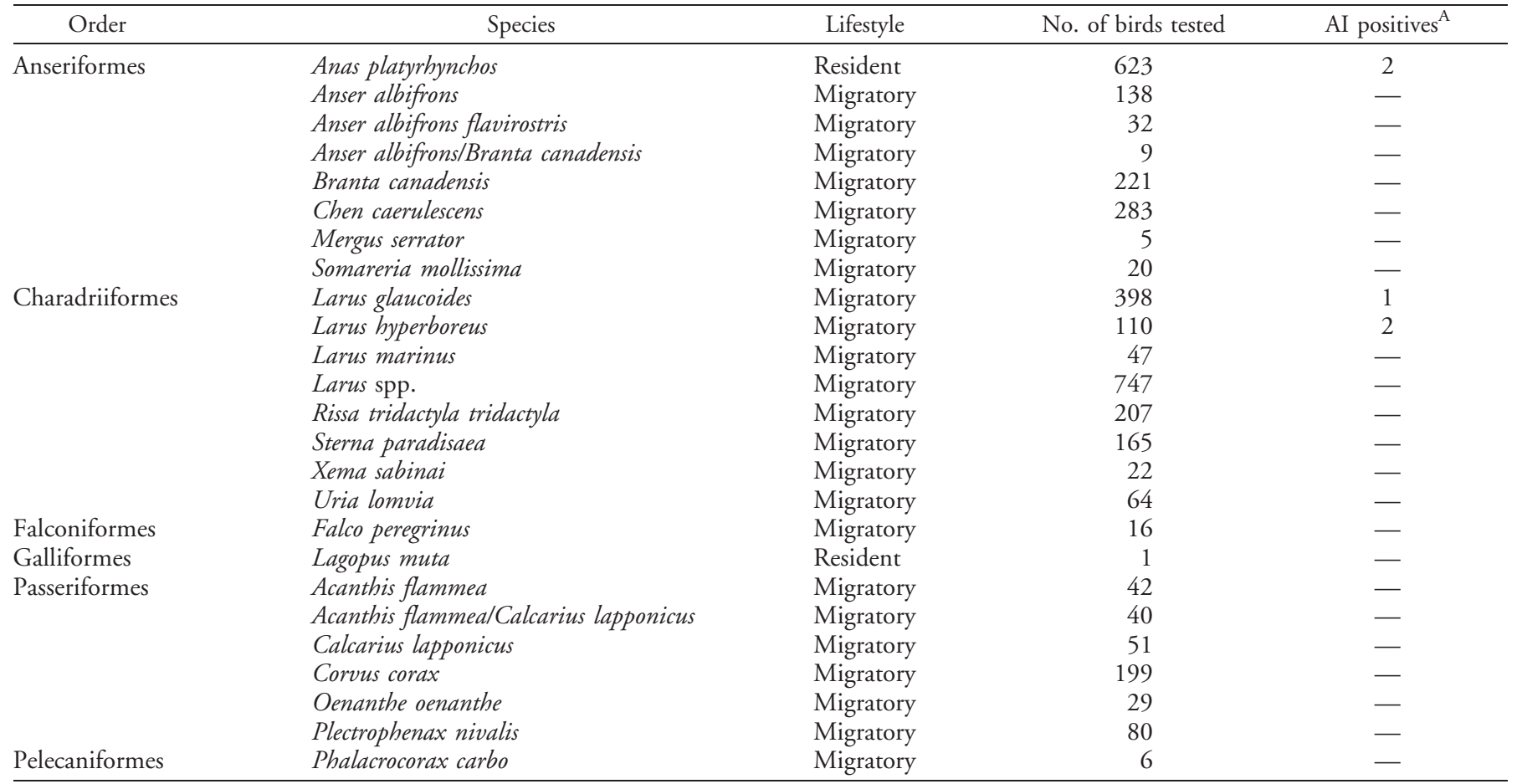

\footnotetext{
${ }^{A}$ No. of influenza A-positive samples. None of the positive samples were H5/H7 by RT-PCR, and viruses could not be isolated.
} 


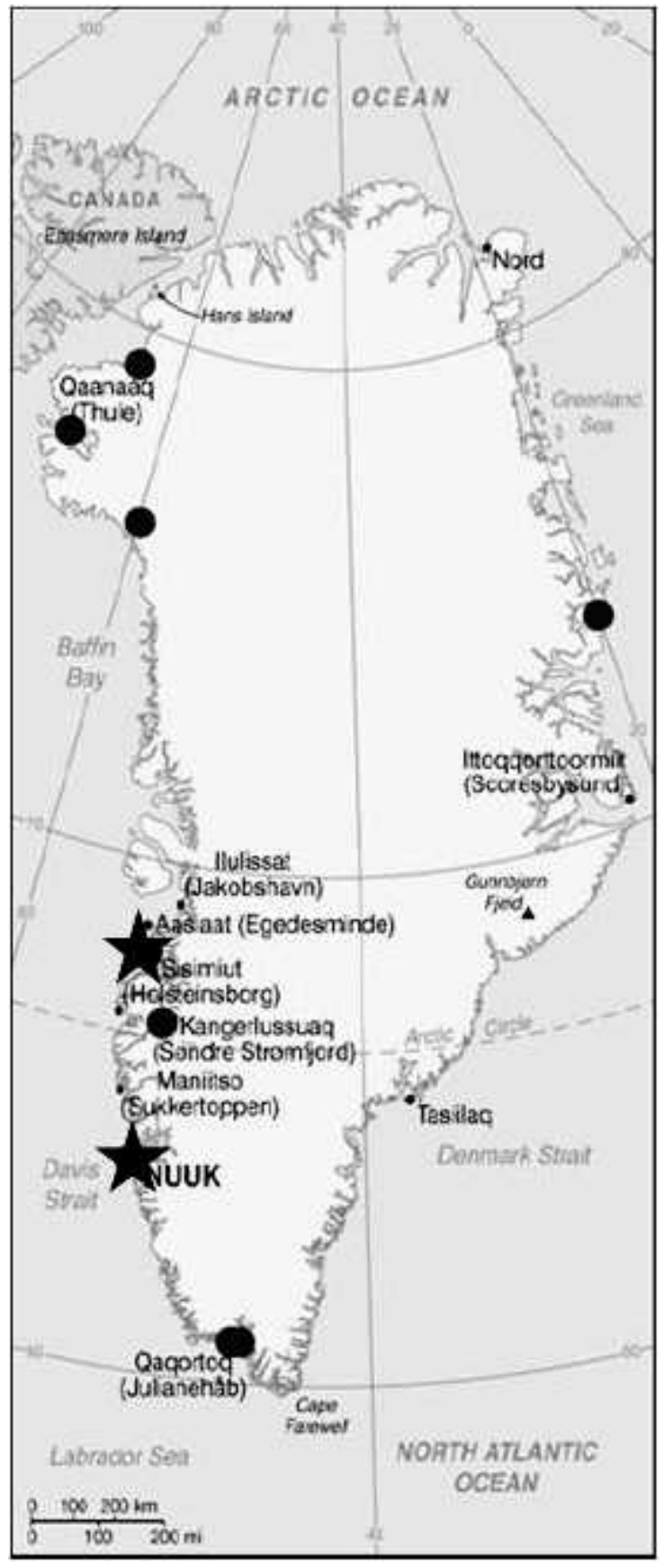

Fig. 2. Sampling locations in Greenland, 2007-10. Dots indicate locations at which all samples were influenza A virus negative, and stars represent locations at which some samples were positive for influenza A virus.

hemagglutinating activity. At least two serial blind passages were made. Isolated viruses were subtyped by hemagglutination inhibition test against a reference panel of H1-H16 antisera (7). Neuraminidase inhibition assay for $\mathrm{N}$ typing (1) was performed against a reference panel of N1-N9 antisera.

\section{RESULTS AND DISCUSSION}

Samples from 11,055 wild birds were collected in Denmark during the 2007-10 period (Tables 1, 2; Fig. 1). Of these, 396 birds were found dead or sick in nature across the country and throughout the year. Four of the dead birds were positive for AI by RT-PCR: a mallard from spring 2009 was LPAI H7 positive; a sparrow hawk and a mute swan from spring 2010 were positive for AI but non-H5/ H7 by RT-PCR; and H3N2 virus was isolated from a mallard found in the autumn of 2010 .

A total of 10,659 live wild birds were included in the active surveillance in Denmark. Samples were taken either as fecal swabs from fresh droppings or as oropharyngeal and cloacal swabs from each bird; birds were caught live by net, trap, or by hand or were shot. Altogether, samples from 536 birds were positive by M-gene RT-PCR, and these were mainly fecal swabs and cloacal swabs, rather than oropharyngeal swabs, and were from waterfowl (Table 2). Subtyping by RT-PCR showed that 69 birds were of the $\mathrm{H} 5$ subtype, and 10 were of the $\mathrm{H} 7$ subtype. All were LPAI by sequencing of HA cleavage site. The rest were categorized as non$\mathrm{H}$ 5/H7 subtype. All RT-PCR-positive samples were subjected to virus isolation, and a variety of virus subtypes were detected (Table 3). Virus isolation was most successful from fecal or cloacal swabs from the "live bird" and "shot game" categories, although the total isolation rate was only $6 \%$ of the PCR-positive samples. Only one of the virus isolates originated from a dead bird. The reason for this result may be suboptimal storage of the samples prior to virus isolation. Viruses in dead birds may be deteriorated as a result of decomposition of the birds in nature because of the time it takes before the bird is found and delivered to the laboratory. The storage temperature, and especially the freeze-thaw cycles of genetic material, may also have a considerable negative effect on the isolation success rate. The rate of success for isolation of viruses was $0.25 \%, 0.32 \%, 0.51 \%$, and $0.12 \%$ for the total number of birds sampled in 2007, 2008, 2009, and 2010, respectively. Although only a few viruses were isolated each year, the especially low success rate observed in 2010 is likely explained by the fact that in that year many samples were stored temporarily at $-20 \mathrm{C}$, rather than at $-80 \mathrm{C}$, prior to analysis.

A total of 33 viruses representing 15 different subtype combinations were isolated. H6N2 and H3N8 were isolated from four birds each; thus, these subtypes were the most frequently encountered. One $\mathrm{H} 5 \mathrm{~N} 2$ virus, one $\mathrm{H} 7 \mathrm{~N} 1$ virus, and three $\mathrm{H} 7 \mathrm{~N} 2$ viruses were isolated. The remaining subtypes observed were isolated from only one or two birds apiece. The variety of virus subtypes is similar to the results of a previous study (9) from Denmark in 2003, the most distinct difference being the finding of four H7 virus isolates in 2009.

Transmission of AI viruses between domestic poultry and wild birds has been inferred (e.g., 5,15). The most recent outbreaks of AI in Danish poultry involved three cases of H7N1 in 2008 (15) and 2010 (authors' unpubl. data). At least two of these cases involved flocks with access to outdoor facilities. This correlates with the contemporary finding of $\mathrm{H} 7 \mathrm{~N} 1$ in the wild bird population, although phylogenetic analyses of the viral genomic segments are necessary to support the assumption of transmission of AI between wild birds and poultry. However, the occurrence of AI subtypes in the wild bird population may pose a risk for $\mathrm{AI}$ infections in Danish poultry.

In Greenland, a total of 3555 wild birds were sampled (Table 4; Fig. 2). In 2007, fecal samples from two mallards sampled at Nuuk and Sisimiut and a single Iceland gull sampled at Sisimiut were positive for influenza RT-PCR targeting the M-gene. These results were confirmed by sequencing of the PCR amplicons. In 2010, two fecal samples from Glaucous gulls collected in Nuuk gave positive results via $\mathrm{M}$-gene RT-PCR. All of these samples were negative by H5- and H7-specific RT-PCRs. Virus isolation was unsuccessful, and further subtyping was not performed. 
The data showed the presence of LPAI viruses in Greenland, although these viruses were likely of low prevalence. However, the logistic and technical challenges involved in collection of samples limited the number of species and areas that were included in the study and also may have caused deterioration of the sample quality, resulting in the very few viruses detected. Thus, the prevalence might be underestimated in this study.

Mallards are resident birds in Greenland and inhabit areas along with migratory species such as Greenland white-fronted geese and Canada geese wintering in northwest Europe and North America, respectively. If transmission occurs between wild bird species, mallards may serve as a vector for the transmission of AI virus between species of different geographic origins. AI viruses are regularly isolated from gulls (16), which have the potential for longdistance dispersal, thus constituting a risk for transmission of AI. The surveillance in Greenland was initiated primarily as a result of the H5 HPAI outbreak in Europe in 2006 to investigate Greenland's potential role as a route of transmission of $\mathrm{H} 5$ HPAI between continents $(7,13)$. No HPAI was detected in Greenland, however, a finding that is in agreement with the lack of reports of H5 HPAI in wild birds in North America. Although we did not find evidence of viruses being transmitted between Denmark and Greenland in this study, transmission between Europe and North America via Greenland cannot be excluded.

\section{REFERENCES}

1. Alexander, D. J. Comparison of the neuraminidases of three avian paramyxoviruses. Arch. Gesamte Virusforsch. 44:28-34. 1974.

2. Alexander, D. J. Summary of avian influenza activity in Europe, Asia, Africa, and Australia, 2002-2006. Avian Dis. 51:161-166. 2007.

3. Bragstad, K., P. H. Jørgensen, K. J. Handberg, and A. Fomsgaard. Genome characterization of the newly discovered avian influenza A H5N7 virus subtype combination. Arch. Virol. 152:585-593. 2007.

4. Bragstad, K., P. H. Jørgensen, K. Handberg, A. S. Hammer, S. Kabell, and A. Fomsgaard. First introduction of highly pathogenic $\mathrm{H} 5 \mathrm{~N} 1$ avian influenza A viruses in wild and domestic birds in Denmark, Northern Europe. Virol. J. 4:43. 2007.

5. Bragstad, K., P. H. Jørgensen, K. J. Handberg, S. Mellergaard, S. Corbet, and A. Fomsgaard. New avian influenza A virus subtype combination $\mathrm{H} 5 \mathrm{~N} 7$ identified in Danish mallard ducks. Virus Res. 109:181-190. 2005.

6. Brown, I. A. Summary of avian influenza activity in Europe, Asia, and Africa, 2006-2009. Avian Dis. 54:187-193. 2010.
7. [CEC] Commission of the European Communities. Council Directive 2006/437/EF. Approving a Diagnostic Manual for Avian Influenza as Provided for in Council Directive 2005/94/EC. OJ L 237:1-27. 2006.

8. Dennis, J. V. A summary of banded North American birds encountered in Europe. North Am. Bird Bander 6:88-96. 1981.

9. Handberg, K. J., O. R. Therkildsen, and P. H. Jørgensen. Genetic analysis of avian influenza virus from wild birds and mallards reared for shooting in Denmark. Avian Dis. 54:420-425. 2010.

10. Jørgensen, P. H., O. L. Nielsen, C. H. Hansen, R. J. Manwell, J. Banks, and D. J. Alexander. Isolation of influenza A virus, subtype H5N2, and avian paramyxovirus type 1 from a flock of ostriches in Europe. Avian Pathol. 27:15. 1998.

11. Makarova, N. V., N. V. Kaverin, S. Krauss, D. Senne, and R. G. Webster. Transmission of Eurasian avian $\mathrm{H} 2$ influenza virus to shorebirds in North America. J. Gen. Virol. 80:3167-3171. 1999.

12. Olsen, B., V. J. Munster, A. Wallensten, J. Waldenstrom, A. D. Osterhaus, and R. A. Fouchier. Global patterns of influenza virus in wild birds. Science 312:384-388. 2006.

13. Shoham, D., and S. O. Rogers. Greenland as a plausible springboard for trans-Atlantic avian influenza spread. Med. Hypotheses 67:1460-1461. 2006.

14. Slomka, M. J., V. J. Coward, J. Banks, B. Z. Löndt, I. H. Brown, J. Voermans, G. Koch, K. J. Handberg, P. H. Jørgensen, M. CherbonnelPansart, V. Jestin, G. Cattoli, I. Capua, A. Ejdersund, P. Thorén, and G. Czifra. Identification of sensitive and specific avian influenza polymerase chain reaction methods through blind ring trials organized in the European Union. Avian Dis. 51:227-234. 2007.

15. Therkildsen, O. R., T. H. Jensen, K. J. Handberg, K. Bragstad, and P. H. Jørgensen. Low pathogenic avian influenza $(\mathrm{H} 7 \mathrm{~N} 1)$ transmission between wild ducks and domestic ducks. Zoonoses Public Health 58:312-317. 2011.

16. Wille, M., G. J. Robertson, H. Whitney, M. A. Bishop, J. A. Runstadler, and A. S. Lang. Extensive geographic mosaicism in avian influenza viruses from gulls in the Northern Hemisphere. PLoS ONE 6:e20664. 2011.

\section{ACKNOWLEDGMENTS}

This study was supported by the Danish Veterinary and Food Administration, the European Union Commission, and the U.S. Department of Agriculture. We thank Flemming Bager (National Veterinary Institute) for assisting with planning of the surveillance in Greenland. We also thank the gamekeepers, hunters, Danish Hunters Association, Danish bird ringers, and everyone else who assisted us in collecting samples from the birds. In particular, we wish to thank Hans Mølgaard, Gunnar Mylius Pedersen, and Jens Peder Hounisen for their assistance in Greenland. 